Nowacka Agnieszka, Śniegocki Maciej, Smuczyński Wojciech, Woźniak-Dąbrowska Kamila. Simultaneous occurrence of C5 vertebral angioma and C5-C6 discopathy and stenosis - case report. Journal of Education, Health and Sport. 2021;11(01):69-74. eISSN 2391-8306. DOI http://dx.doi.org/10.12775/JEHS.2021.11.01.007

https://apcz.umk.pl/czasopisma/index.php/JEHS/article/view/JEHS.2021.11.01.007

https://zenodo.org/record/4446265

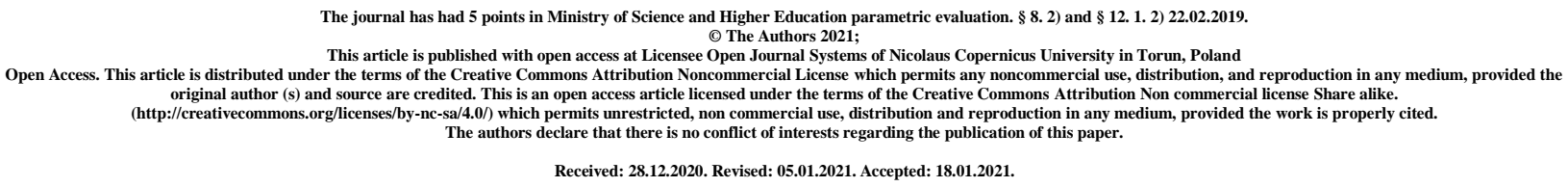

\title{
Simultaneous occurrence of C5 vertebral angioma and C5-C6 discopathy and stenosis - case report
}

\author{
Agnieszka Nowacka ${ }^{1}$, Maciej Śniegocki ${ }^{1}$, Wojciech Smuczyński ${ }^{2}$, \\ Kamila Woźniak-Dąbrowska ${ }^{1}$
}

${ }^{1}$ Department of Neurosurgery, Nicolaus Copernicus University Collegium Medicum in Bydgoszcz, Poland

${ }^{2}$ Department of Physiotherapy, Nicolaus Copernicus University Collegium Medicum in Bydgoszcz, Poland

\begin{abstract}
Introduction. Vertebral angioma is a benign tumor of blood vessels. Since they usually do not cause any pain, they are usually diagnosed by accident while diagnosing other conditions within the spine. In case when pain occurs and persists or even intensifies a vertebroplasty should be performed.

Case presentation. A 50-year-old patient admitted to the Neurosurgery Department for surgical treatment of C5 vertebral angioma and C5-C6 stenosis and discopathy. In physical examinations on admission: general condition good, back pain at the lower part of the cervical spine, neck pain radiating to the left upper limb, no sensory disturbance. Based on the clinical symptoms and the MRI image, the patient was qualified for simultaneous surgical decompression of C5-C6 stenosis and C5 vertebroplasty. Because of the C5 vertebral angioma shown in MRI, administration of PMMA was performed in a first step, for vascular coagulation and restoration of C5 vertebral strength, and a discectomy with decompression and implantation of cage at C5-C6 level in a second step. After the surgery the patient's condition improved, pain ailments regressed.

Conclusion. The decision and choice of vertebral angiomas treatment must be based both on the clinical symptoms and the MRI image. In case of surgical management of simultaneous occurrence of vertebral angioma and discopathy and stenosis, vertebroplasty should be performed first, followed by decompression and cage implantation.
\end{abstract}

Key words: vertebral angioma; vertebroplasty; stenosis; decompression; cervical spine 


\section{Introduction}

Vertebral angioma is a benign tumor of blood vessels. In most clinical cases, it does not cause any pain or other symptoms. A minor pain at the lesion level occurs rarely.

Vertebral angioma is caused by arterial hyperplasia in the vertebral body. This results in the disappearance of bone structure in favor of developing vascular network. If the vertebral angioma does not cause any pain, it is not treated and no routine checkups are required. In case when pain occurs and persists or even intensifies, surgery is necessary.

Vertebral angiomas that are located within the vertebrae are diagnosed quite often. To diagnose them, the radiological examination is used primarily - classical radiography, computer tomography, magnetic resonance. In the obtained image, there are many cystic lesions in the bone structure of the vertebral body. Since vertebral angiomas usually do not cause any pain, they are usually diagnosed by accident while diagnosing other conditions within the spine.

Percutaneous vertebroplasty is a minimally invasive procedure that involves the injection of a PMMA (polymethyl methacrylate) into the diseased vertebral body, which results in filling of the bone structure, strengthening of the vertebral body and reduction of pain. The main indications for vertebroplasty are compression fractures of vertebral bodies in the course of osteoporosis, vertebral angiomas and cancer metastases to vertebral bodies. The decision on vertebroplasty is made when the patient suffers from severe pain because of the vertebral angioma and when the image of the study indicates that this lesion is present. PMMA is injected into the place where the vascular network is formed. While polymethyl methacrylate is thickening, exothermic reaction generates heat and angioma, as well as ends of sensory nerves, undergo complete coagulation. The cause of the disease in the vertebral body is thus completely eliminated, and the weakened vertebrae is strengthened by PMMA, which penetrates the bone.

\section{Case presentation}

A 50-year-old patient was admitted to the Neurosurgery Department for surgical treatment of C5 vertebral angioma and C5-C6 stenosis and discopathy (Figure 1).

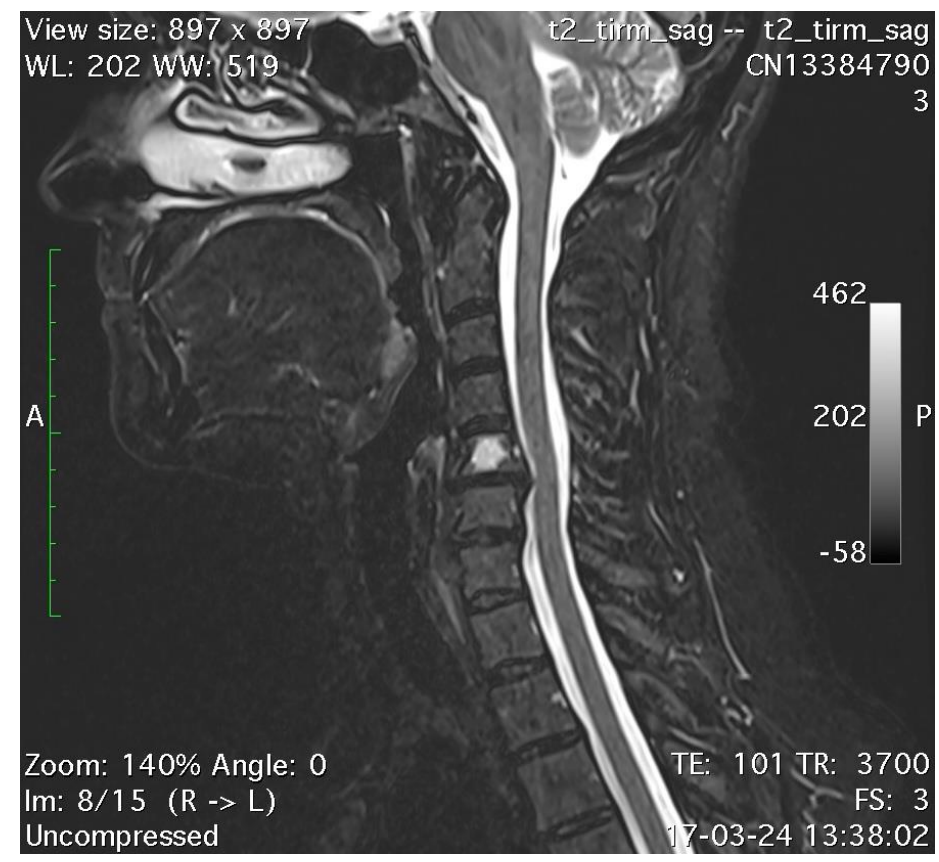

Figure 1. MRI of the cervical spine. Visible C5 vertebral angioma and discopathy and stenosis at the C5-C6 level - own material of the Neurosurgery Department of the University Hospital No. 1. dr. A. Jurasz in Bydgoszcz. 
In physical examinations on admission: general condition good, back pain at the lower part of the cervical spine, neck pain radiating to the left upper limb, no sensory disturbance. Based on the clinical symptoms and the MRI image, the patient was qualified for simultaneous surgical decompression of C5-C6 stenosis and C5 vertebroplasty.

The procedure confirmed the presence of C5-C6 stenosis. C5 vertebral body was located with the use of the X-ray. A sample was taken for histopathological examination. Vertebroplasty was performed in a standard way, under visual control. In the next step, a fibrous ring was cut at C5-C6 level and disc masses were removed. After visualization of the dural sac and hemostatic control, a cage 5 was adjusted and implanted. Intraoperative radiological monitoring showed the correct placement of implants. After the surgery the patient's condition improved, pain ailments regressed. Early postoperative rehabilitation was implemented. On the third day after the procedure, the patient in a good general condition was discharged from the clinic.

\section{Discussion}

For the first time, vertebroplasty has been used to treat vertebral angioma by a team of neurosurgeons and neuroradiologists from Amiens, France (P. Galibert, H. Deramont, P. Rosat, D. Le Gars), and the methodological description and preliminary results were published in 1987 [1]. This paper describes the elimination of severe cervical spine pain in a young patient by introducing methyl polymethacrylate (PMMA) into the $\mathrm{C} 2$ vertebral body, which has been partially destroyed by an aggressive hemangioma. Deramont initially used PMMA in pathological fractures because of primary and metastatic tumors, and in vertebral angiomas, and then applied this method to treat compression fractures in osteoporosis. Deramont et al. presented results of procedures in more than 20 patients treated for vertebral angiomas.

Later, this method was used to fill out the osteolytic lesions of the vertebral body caused by tumors metastases (multiple myeloma) and to treat pathological fractures in osteoporosis. The first description of this procedure was done by a group of neuroradiologists from the University of Virginia [2]. In Poland, vertebroplasty for the first time was used by Tomasz Trojanowski [3]. The first use of vertebroplasty in the treatment of osteoporotic fractures and tumor metastases and vertebral angiomas, took place in 1999 in the Department of Neurosurgery, Military Medical Academy in Lodz $[4,5,6]$.

At present, the use of verterbroplasty is the method of choice in the treatment of osteoporotic vertebral fractures in many countries and is included in the guidelines of many radiological, orthopedic and neurosurgical societies dealing with osteoporosis and spinal fractures.

Nowdays vertebroplasty is performed exclusively with standardized kits containing properly prepared PMMA's. Visualization of cement during injection and careful monitoring of any PMMA's extraction is the key to safe vertebroplasty.

In the case of vertebral angioma, the following theories have been proposed to explain the mechanisms of pain relief following vertebroplasty [7], which are: thermic necrosis of nerve endings, cement toxicity affecting pain receptors, concept of mechanical stabilization [8]. It has been found that the chemical products produced during the cement polymerisation reaction can be neurotoxic $[8,9]$. Cement toxicity is also important in the formation of necrotic zone around the angioma [10]. The area of the necrotic zone may also depend on the exothermic polymerization of the cement [10]. Angioma's tissues may be more sensitive to the effects of cement than normal tissues. Another mechanism responsible for possible necrotic zones of angioma is ischemia, which may be due to direct causes - clogging of vessels by cement, or indirect - vascular compression.

Cotten et al. [11] found no correlation between the volume of administered PMMA and clinical outcomes. Clinical experience confirms that incomplete filling of the vertebral body usually results in pain relief, significantly reducing the risk of complications, in the form of cement leakage $[11,12,13]$. Recent studies have shown that relatively small volumes of cement are needed to restore the vertebral strength: $4.4 \mathrm{ml}$ in the lumbar segment, $3.1 \mathrm{ml}$ in the lumbar-thoracic segment, and $2.5 \mathrm{ml}$ in the thoracic segment [14]. 
Initially, vertebroplasty in the case of vertebral angiomas was performed only by double-sided cement injection. There were also concerns about whether unilateral injection of cement could provide sufficient stability. Recent studies have shown that unilateral administration of cement, which passes through the midline of the stem, may provide sufficient restoration of vertebral strength, while at the same time decreasing the risk of cannulas passing through the vertebral pedicle [15].

Anatomical considerations also require analysis of the vertebral body volume in normal conditions and after compression fracture of the vertebrae. In order to prevent excessive supply of cement to the vertebral body, it is useful to review the estimate data of each vertebral body volume, with the use of computer-determined data of volume values in the cervical, thoracic and lumbar segments [16]. They range from $7.2 \mathrm{~cm}^{3}$ in the cervical (C5) to $22.4 \mathrm{~cm}^{3}$ in the lumbar (L3) segment. Due to the thickness of the vertebral's body compact substance, it is to be expected that the filling volume usually does not exceed half the value of the theoretical volume. The final fill volume is also decreased by the presence of vertebral body collapse. In the case presented by us, approximately $1.8 \mathrm{ml}$ of PMMA was administrated at approximately 30 degrees in the sagittal plane (Figure 2).

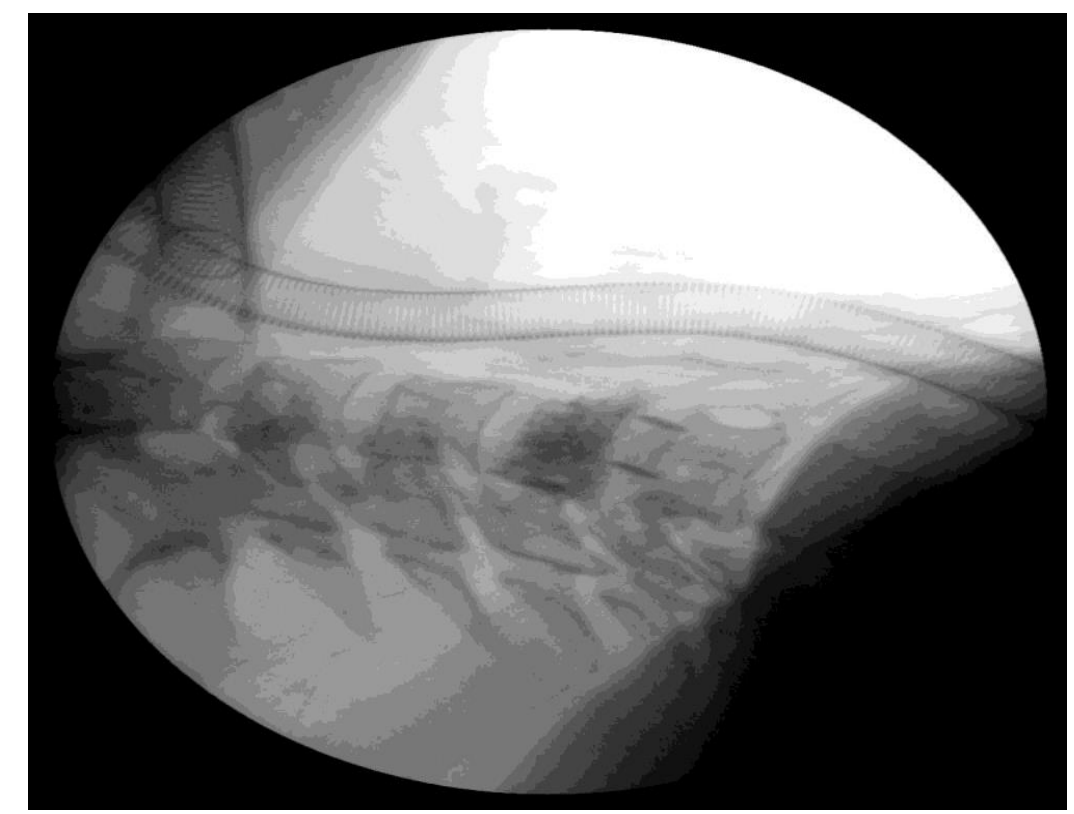

Figure 2. Intraoperative radiological monitoring, condition after PMMA's admission to C5 vertebral angioma - own material of the Neurosurgery Department of the University Hospital No. 1. dr. A. Jurasz in Bydgoszcz. 
Subsequently, during the same surgery, a typical (classical technique, anterior approach) decompression of C5-C6, with cage implantation, was performed (Figure 3).

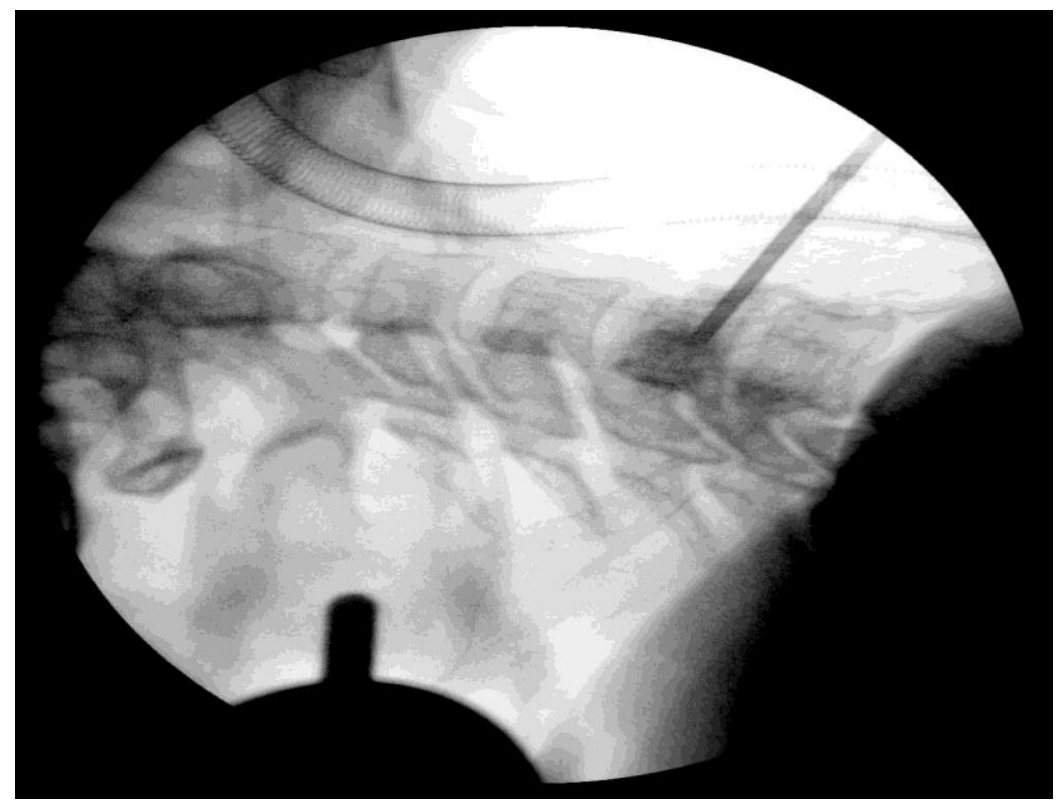

Figure 3. Intraoperative radiological monitoring, condition after PMMA's admission to C5 vertebral angioma and decompression at C5-C6 - own material of the Neurosurgery Department of the University Hospital No. 1. dr. A. Jurasz in Bydgoszcz.

In presented clinical case, beside a root pain, the patient suffered from a neck pain syndrome. Because of the C5 vertebral angioma shown in MRI, we decided to administer PMMA at first, for vascular coagulation and restoration of C5 vertebral strength, and secondly perform a discectomy with decompression and implantation of cage at C5-C6 level. Immediately after the procedure and at outpatient check-up after 3 weeks from surgery, the patient's condition improved and pain ailments regressed.

\section{References}

1. Galibert P, Deramond H, Rosat P, Le Gars D. Preliminary note on the treatment of vertebral angioma by percutaneous acrylic vertebroplasty [in French]. Neurochirurgie 1987; 33:166-8. https://pubmed.ncbi.nlm.nih.gov/3600949/

2. Jensen ME, Evans AJ, Mathis JM, Kallmes DF, Cloft HJ, Dion JE. Percutaneous polymethylmethacrylate vertebroplasty in the treatment of osteoporotic vertebral body compression fractures: technical aspects. AJNR Am J Neuroradiol 1997; 18:1897-904.

https://pubmed.ncbi.nlm.nih.gov/9403451/

3. Trojanowski T, Kamiński S, Janczarek M, Trojanowska M. Methyl methacrylate embolisation and stabilisation of vertebral haemangioma. Zentrabl. Neurochirurg 1998 (Supll); 154S.

https://webcache.googleusercontent.com/search?q=cache:NurqNLMru8UJ:https://journals.v iamedica.pl/neurologia_neurochirurgia_polska/article/download/60762/45960+\&cd=1\&hl=pl\&ct=c lnk\&gl=pl\&client=safari

4. Zapałowicz K., Radek A., Błaszczyk B. i wsp. Przezskórna plastyka kręgów. Wskazania technika i możliwości. Neurol Neurochir Pol 2001

5. Zapałowicz K., Radek A., Błaszczyk B. i wsp. Przezskórna wertebroplastyka cementem kostnym jako metoda leczenia kompresyjnych złamań kręgów na tle osteoporozy. Ortopedia Traumatologiai Rehabilitacja 2003; 5:34-9.

6. Zapałowicz K., Radek A., Błaszczyk B. i wsp. Przezskórna wertebroplastyka cementem kostnym w leczeniu naczyniaków i nowotworów kręgosłupa. Ortopedia Traumatologia Rehabilitacja 2003; 5:185-8. 
7. Belkoff SM, Fenton DC, Scribner RM, Reiley MA, Talmadge K, Mathis JM. An in vitro biomechanical evaluation of an inflatable bone tamp used in the treatment of compression fracture. Spine 2001; 26:151-6. https://pubmed.ncbi.nlm.nih.gov/11154534/

8. Bostrom MP, Lane JM. Future directions: augmentation of osteoporotic vertebral bodies. Spine 1997; 22:38S-42S. https://pubmed.ncbi.nlm.nih.gov/9431643/

9. Dahl OE, Garvik LJ, Lyberg T. Toxic effects of methylmethacrylatemonomer on leukocytes and endothelial cells in vitro [published erratum appears in Acta Orthop Scand 1995;66: 387]. Acta Orthop Scand 1994; 65:147-53. https://pubmed.ncbi.nlm.nih.gov/8197846/

10. San Millan RD, Burkhardt K, Jean B, et al. Pathology findings with acrylic implants. Bone 1999; 25:85S-90S. https://www.researchgate.net/publication/12842216_Pathology_findings_with_acrylic_impl ants

11. Cotten A, Dewatre F, Cortet B, et al. Percutaneous vertebroplasty for osteolytic metastases and myeloma: effects of the percentage of lesion filling and the leakage of methyl methacrylate at clinical follow-up. Radiology 1996; 200:525-30. https://pubmed.ncbi.nlm.nih.gov/8685351/

12. Jensen ME, Evans AJ, Mathis JM, Kallmes DF, Cloft HJ, Dion JE. Percutaneous polymethylmethacrylate ertebroplasty in the treatment of osteoporotic vertebral body compression fractures:technical aspects. AJNR Am J Neuroradiol 1997; 18:1897-904. https://pubmed.ncbi.nlm.nih.gov/9403451/

13. Mathis JM, Petri M, Naff N. Percutaneous vertebroplasty treatment of steroid-induced osteoporotic compression fractures. Arthritis Rheum 1998; 41:171-7. https://onlinelibrary.wiley.com/doi/abs/10.1002/1529-0131(199801)41:1\%3C171::AID-

ART21\%3E3.0.CO;2-5

14. Belkoff S, Deramond H, Mathis J, Jasper L. Vertebroplasty: the biomechanical effect of cement volume (abstract). Trans Orthop Res Soc 2000; 25:356. https://europepmc.org/article/med/11462082

15. Tohmeh AG, Mathis JM, Fenton DC, Levine AM, Belkoff SM. Biomechanical efficacy of unipedicular versus bipedicular vertebroplasty for the management of osteoporotic compression fractures. Spine 1999; 24:1772-6. https://pubmed.ncbi.nlm.nih.gov/10488505/

16. Mathis J.M. Deramond H., Belkoff S.M. (eds.), Percutaneous Vertebroplasty and Kyphoplasty 2nd ed Springer, 2006. 